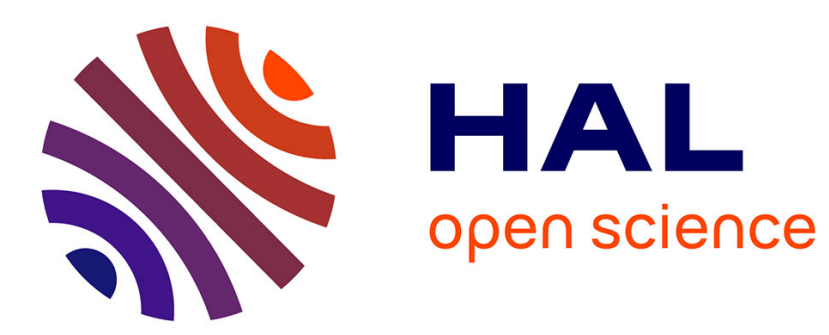

\title{
Progressive growth deterioration in a context of nutritional transition: a case study from Vientiane (Lao PDR).
}

\author{
Eric Benefice, Pierre Lévi, Phonethip Banouvong
}

\section{- To cite this version:}

Eric Benefice, Pierre Lévi, Phonethip Banouvong. Progressive growth deterioration in a context of nutritional transition: a case study from Vientiane (Lao PDR).. Annals of Human Biology, 2012, 39 (3), pp.239-46. 10.3109/03014460.2012.681803 . ird-00710064

\section{HAL Id: ird-00710064 https://hal.ird.fr/ird-00710064}

Submitted on 20 Jun 2012

HAL is a multi-disciplinary open access archive for the deposit and dissemination of scientific research documents, whether they are published or not. The documents may come from teaching and research institutions in France or abroad, or from public or private research centers.
L'archive ouverte pluridisciplinaire HAL, est destinée au dépôt et à la diffusion de documents scientifiques de niveau recherche, publiés ou non, émanant des établissements d'enseignement et de recherche français ou étrangers, des laboratoires publics ou privés. 


\section{Progressive growth deterioration in a context of nutritional transition: a case study from Vientiane (Lao PDR)}

Running title: Stunting in Vientiane

Corresponding author:

Eric Benefice (MD, $\mathrm{PhD})$

Address: IRD (Institut de Recherche pour le développement, France), Ban Sisangvone, Saysettha district PO box: 5992, Vientiane (PDR Lao)

Phone: (856 21) 452707

Fax: (856 21) 412993

Mobile: (856 20) 7526834

Email: eric.benefice@ird.fr

Contributing authors:

Pierre Lévi, Pierre.Levi@ird.fr

Phonetip Banouvong, louang_laos@hotmail.com

Key words: Stunting, Food Diversity Score, urbanization, sex difference 


\title{
Progressive growth deterioration in a context of nutritional transition: a case study from Vientiane (Lao PDR)
}

\begin{abstract}
Background

The high rates of rapid urban and economic growth occurring in Asia are bringing about parallel changes in both food consumption patterns and nutritional status.
\end{abstract}

Aim

The aim of this study is to examine the impact of these changes on the nutritional and health status of mothers and their offspring in Vientiane, Lao PDR.

\section{Methodology}

Over two consecutive years, a follow-up study of 150 infant-mother pairs living at three different levels of urbanization was performed in Vientiane. The mothers completed a questionnaire on their eating habits. Clinical examinations and anthropometric measurements were also carried out.

\section{Results}

The results showed that, in general, the dietary energy content was low (providing only $83 \%$ of the energy requirement) and there were deficiencies in calcium, vitamin A, Folate folates and iron. The main energy source was rice (providing $40.9 \%$ ) while $40 \%$ of the protein was provided by meat with fish providing $19.8 \%$. The differences observed in the food contribution to energy intakes and in food diversity varied with the level of urbanization. The prevalence of stunting $(13.9 \%$; CI $10.0 \sim 18.6 \%)$ was less than that reported at the country level. Stunting was related to age, the sex of the child, and the mother's physique and varied according to the level of urbanization.

\section{Conclusion}

The level of urbanization in Vientiane influences the pace of the ongoing process of nutritional transition. 
Key words: Stunting, Food Diversity Score, urbanization, sex differences 


\section{Introduction}

The changes in the eating habits and nutritional status that have occurred in the developing world over the last two decades are generally termed "nutritional transition". Nutritional transition is characterized by an alteration in eating habits (the increased consumption of refined foods and the abandonment of the traditional starchy and high-fibre diet) and a decline in the level of physical activity. The present worldwide epidemic of overweight and obese individuals is presumed as being the consequence of this nutritional transition in those countries experiencing fast rates of economic growth and urbanization (Popkin and GordonLarsen 2004).

In Asia, it is certain that epidemics of overweight individuals have developed in parallel with the speed of industrialization and urbanization (Misra and Khurana 2009; Zhai et al. 2009; Misra et al. 2011). Not only are affluent upper and middle social classes affected, but also poor people living in urban slums or in economically backward rural areas can be exposed (Misra and Khurana 2009). Paradoxically, several regions affected by the epidemics in overweight adults, are at the same time hit by child undernutrition (malnutrition) (Khan and Khoi 2008). It is a fact that malnutrition is still widespread in Asia. About 100 million pre-school children were estimated as suffering from malnourishment in 2010 (de Onis et al. 2012). The most prevalent form, that of chronic malnutrition, manifests itself as growth retardation or stunting (Waterlow 1972). One of the most worrying problems of stunting is the trans-generational consequences (Ozaltin et al. 2011). This means that stunted girls become short adult women who, in turn, give birth to low birth weight and small for gestational age babies that will in turn be affected by growth retardation (Ferreira et al. 2009; Dewey and Begum 2011). However, the situation has changed since the turn of the century and the future looks brighter. The nutritional situation in Asia has improved dramatically in that the prevalence of stunting in pre-school aged children has decreased from $52 \%$ to $34 \%$ in two decades (de Onis et al. 2000). This is confirmed by a more recent evaluation which reported a further spectacular reduction from $49 \%$ to $28 \%$ in 2010 (de Onis, Blossner et al. 2012). However advances are not uniform and there still exist great differences both between and within countries. 
The probable link between two events, the decline in malnutrition and the occurrence of nutritional transition is an important issue in the better understanding of the natural history of malnutrition. The dilemma is how to take advantage of the impact of economic improvements on health in order to reduce child malnutrition without the disadvantage of later paying an outrageous price in terms of adult chronic diseases. Analyzing the nutritional transition phenomenon at its very beginning could help solve this dilemma. The present situation in the Lao People's Democratic Republic (Lao PDR) may contribute to this analysis. Lao PDR is the least populated country in South-East Asia (with about 6 million inhabitants) and one of the less economically developed. However, important economic advances have recently taken place. Lao PDR is no longer considered as a "less economically developed country" by the World Bank, but is now classified as a "lower middle income" country. Nevertheless, according to the World Food Programme (WFP 2011), economic growth has not led to a parallel improvement in the nutritional status. Food insecurity is still a challenge in rural and mountainous areas(WFP 2011) with great disparities existing between the northern highlands where stunting is very frequent (58\%) and the urban areas of the Mekong plain, were the prevalence is much lower (35\%) (Anonym 2006).

In this paper, data on the nutritional status and eating habits of children and their mothers living in the districts of Vientiane (Capital City) at different levels of urbanization are presented. The objectives of the present paper are 1) to examine the relationships between urban development, nutritional status and food eating patterns and 2) to look at the association between maternal status and growth of the offspring.

\section{Methods}

\section{Study site and sampling}

The metropolitan area of Vientiane is loosely urbanized and comprises 148 administrative units named ban or villages. Thirteen human and environmental indicators (Vallée 2008) together with aerial photographs and the most recent census data (of 1995 and 2005) were used to classify the different zones of the city according to their "level of urbanization". These indicators were representative of both environmental and demographic characteristics (house construction; demographic density; public infrastructure; markets; water supply; electricity supply; schools; hospitals; shops; adequate sewerage; people whose main activity was agriculture; distance to main road; distance to city center...) and represent a gradient of 
urbanization ranging from the more densely built-up and well equipped areas to those suburbs where agricultural activities are still pursued. Three levels of urbanization (or urbanization strata) were thus identified using a hierarchical forward classification procedure : 1) the central zone (strata 1);2) the first urbanized belt (strata 2): and the second urbanized belt (strata 3) (Vallée 2008).

Sampling followed a two-step procedure. First, nine villages (ban) were randomly drawn from each stratum (making 27 villages in total) and then 1,000 households were randomly drawn from these for a demographic, educational and economic follow-up (Lévi 2009) Finally, within this sample, the youngest women, either pregnant or having just given birth at the beginning of the survey, were selected for an in-depth growth and nutrition survey. A total of 157 (150) mother-infant pairs evenly distributed in the 3 strata (strata 1: 37; strata 2: 61; strata 3: 59), were followed-up over two consecutive years. Mean family size was 6.4 individuals per unit and in our sample, no difference was found between urbanization levels.

\section{Dietary intakes}

Dietary intakes were studied in two different ways. First, a qualitative evaluation was performed using a food frequency questionnaire and applied to mothers. This allowed the building of a food diversity score (FDS) derived from the WFP procedure based on a list of food consumed in the household over the previous seven days (Kennedy et al. 2010). To do this, different weight values were assigned to eight food groups: Group 1: Cereals, tubers and roots (weight $=2$ ); Group 2: meat and fish, (weight $=3$ ); Group 3: milk (weight $=4$ ); Group 4: oil/fat, (weight $=0.5)$; Group 5: fruit $($ weight $=1)$; Group 6: vegetables $($ weight $=1)$; Group 7: pulses (weight $=3$ ); Group 8: sugar, $($ weight $=0.5)$; and condiments $($ weight $=0)$. These food items were the same as those in the food composition table used for the 24 hour dietary recalls as described below.

Second, mothers responded to a 24 hour dietary recall. They were asked to enumerate each meal eaten for breakfast, lunch, dinner and in-between meals on the day preceding the survey. Then they had to list the foods eaten in each meal, together with the cooking methods. The quantities consumed were roughly estimated using common household measures (bowl, glasses, and plates). Portions were then recorded as normal, smaller than normal or larger than normal. Data were computed with Nutrisurvey software (http://www.nutrisurvey.de/). A food 
composition table was compiled from those tables already existing: Nutrisurvey data for Thailand and Germany; United States Department of Agriculture database (http://www.nal.usda.gov/fnic/foodcomp/search/), Food and Agriculture Organization: Food Composition Table for Asia (http://www.fao.org/docrep/003/X6878E/X6878E00.htm); Canadian file of nutrients (http://www.hc-sc.gc.ca/fn-an/nutrition/fiche-nutri-data/indexfra.php). The final file had 252 entries and the analysis of more than 100 nutrients was possible. In practice we analyzed just energy and 23 nutrients. Nutrient requirements were based on recommendations of the German Society for Nutrition (DGE) and the Joint WHO/FAO Committees for Energy and Nutrients. Calculation was done for a 25 - 30 year old woman engaging in light to medium physical activity.

\section{Nutritional status}

The nutritional status was determined on the basis of anthropometric measurements.Measurements were taken according to recommended international techniques (Lohman et al. 1988). The weight $(\mathrm{kg})$ was recorded with an electronic Seca ${ }^{\circledR}$ medical scale (Model 354) accurate to $10 \mathrm{~g}$ in infants and a classical electronic Seca $®$ scale accurate to 100 $\mathrm{g}$ in adults. Recumbent length was measured with a Seca ${ }^{\circledR}$ measuring mat (Model 210) up to the age of 2 years. Standing height was measured with a Harpenden $₫$ anthropometer in mothers and children older than 2 years.

Biceps and triceps subcutaneous skinfolds $(\mathrm{mm})$ were recorded on the right side after marking the site on the skin with a Holtain ${ }^{\circledR}$ caliper. Two successive measurements were performed and the average was used for analysis. Arm circumference was measured at mid-distance between the olecranon and acromion. Arm muscle circumference (AMC, $\mathrm{cm}$ ) was calculated using the formula of Gurney and Jelliffe (Gurney and Jelliffe 1973):

$\mathrm{AMC}=$ arm circumference- $\pi *$ (triceps skinfold).

The same person performed all anthropometric measurements. Stature and subcutaneous skinfolds were measured twice at the beginning and at the end of the visit during the 2 first days of the studies. Intramesurer technical errors were in the lower range of published data (Lohman, Roche et al. 1988).

Anthropometric indices of nutritional status were also calculated using the new WHO reference data set (http://www.who.int/childgrowth/en/). 
The following nutritional indices were calculated: height-for-age $(\mathrm{H}$-age, indicator of chronic malnutrition), weight-for-age (W-age, indicator of global malnutrition) and weight-for-height (W-H, indicator of acute malnutrition). Values were expressed as z-scores from the references.

Finally, the body mass index (BMI, $\mathrm{kg} / \mathrm{m}^{2}$ ) was computed as the weight divided by the square of height and used as an index of corpulence in adult women.

\section{Statistical analysis}

Data were entered and double-checked using Epi Info software. NCSS statistical software was employed (http://www.ncss.com/). All continuous variables were checked for the normality of the distribution. Appropriate transformations were done if necessary. Pearson correlation coefficients to test the association between variables were calculated. We performed general linear models of analysis of variance designed to take into account the visit effect (repetition of measurements from one year to another) in comparing values of continuous variables between different urban strata. Associations between growth indices and mother characteristics were studied through a multiple regression procedure. A hierarchical model was run with a forward selection of variables. Main effects and two-way interaction terms were included. Normality of residual distribution and multi-collinearity between variables were checked.

\section{Ethical consideration}

After formal administrative authorizations had been received from the provincial director of public health, the health directors of each district and the "ban" leaders, the objective of the study was explained in general to each mother individually in the presence of her husband. Then the mothers were asked to sign an informed consent form for themselves and on behalf of their offspring. The Dean of the department of post doctoral studies, Faculty of medicine gave his agreement after consulting the scientific committee. The Lao National Ethics Committee for Health Research (Council of Medical Sciences), Ministry of Health) gave their ethical approval. 


\section{Results}

\section{Differences in food eating patterns}

In general, Lao women had three main meals during the day punctuated by two snacks (mid morning and afternoon). There was a great diversity of foods and recipes. The most frequently consumed food was sticky rice (Oryza sativa var. glutinosa). In addition, women ate non glutinous rice and a variety of dishes made with rice flour: noodle, vermicelli, and ravioli. Chicken and pork consumption was common while beef was eaten less often. Fruits and vegetables were eaten every day. The fish eaten most often were from paddy fields or fish farms and were usually common carp (Cyprinus carpio carpio) or Tilapia (Cichlidae). Wild fish from the Mekong River, though still abundant, were consumed less often because they were more expensive.

Daily intakes of macronutrients are presented in Table I. The daily energy intake of these young women was rather low. They ate about $92 \mathrm{~g}$ of protein which is more than enough to fulfill the estimated daily requirement of $47 \mathrm{~g}$. Table II presents the percentage of the fulfillment of the women's needs. The total energy intake was insufficient by $\mathbf{1 5 \%}$ as was the intake of poly unsaturated fatty acids (20\%), vitamin A (45\%), total folic acid (50\%), calcium (70\%) and iron (25\%). Using a general linear model of variance to take into account the year of visit effect, no relationship was determined between the differences in the fulfillment of energy and nutrients requirements and the levels of urbanization.

Cereals were the most important contributor to the overall energy content of the diet (mean: 40.9\%; exact confidence interval at 95\% ( $\mathrm{CI}$ 95\%): $39.6 \sim 42.3 \%)$; meat was the second (22.6\%; CI 95\%: $21.3 \sim 23.9 \%$ ); fish the third (7.3\%; CI 95\%: 6.4 8.2\%); then fruit (6.6\%; CI 95\%: 5.9 7.3\%); fat (6.7\%; CI 95\%: 6.0 7.4\%) and vegetables (5.5\%; CI 95\%: 5.0 6.0\%). Relative weights of the contribution of the food groups changed in terms of the protein intakes: Meat comprised 48\% (CI 95\%: 45.6 50.4\%) of the protein intake; fish $19.8 \%$ (CI $95 \%$ : 17.6 22.0\%); cereals 15.3\% (CI $95 \%$ : 14.5 16.2\%); and vegetables 6.6\% (CI $95 \%: 6.0$ $7.2 \%)$. All these variables were normally distributed. The relationship between the contribution of the food groups to the energy content of the diet and the level of urbanization was analyzed using a general linear model of analysis of variance (Table III). Women living in the central area (strata 1 ) tended to eat fewer cereals and fish, and more meat and milk than 
did those living at the periphery (strata 2 and 3). There were no differences for the other food groups.

The median of the food diversity score (FDS) calculated for one week was equal to 49.5 (95\% CI: 46 53.5). There existed significant differences according to the level of urbanization ( $\mathrm{F}=$ 3.8; $\mathrm{p}$ <0.02): FDS was significantly lower in the second urbanized belt (strata 2 median: 43) than in the other two belts (strata 1 median: 51.7; strata 3, median: 52.5).

\section{Status of mothers}

A demographic study revealed that a process of demographic transition was already ongoing in Vientiane (with a decrease in both infant and maternal mortality to 24/1000 and 183/100 000 respectively, and low fecundity with a median descent of 3.1 children in 45 year old women). There was also a high percentage in the percentage of The decrease was even higher in women who had attended primary school (to 89\%) (Lévi 2009).

In general, in our study, the mothers were young (mean age: 28.2 years \pm 5.0 ) and in apparent good health at the time of the visit. Table IV reports their physical characteristics. When compared to international references the women were shorter than average with their median heights for standing and sitting below the $5^{\text {th }}$ percentile of the reference (Hamill 1977). However, their weight, arm circumference and triceps skinfolds were slightly over the $25^{\text {th }}$ percentile of the reference data (Hamill 1977; Johnson et al. 1981). They were generally well proportioned: according to their BMI values (WHO 1995), 70.3\% were normal; 9.3\% were thin $\left(\mathrm{BMI}<18.5 \mathrm{~kg} / \mathrm{m}^{2}\right)$ and $20.5 \%$ were overweight $\left(\mathrm{BMI}>25 \mathrm{~kg} / \mathrm{m}^{2}\right)$ but none were obese. Their body mass (weight: $r=0.25, \mathrm{p}<0.0001$ ) and fat mass (skinfold thickness: $r=0.34, \mathrm{p}<$ 0.0001) increased significantly with age. Anthropometric measurements were not related to food intakes nor were they related to the level of urbanization.

The mean blood pressures of the women were $120.7 \pm 12.7 \mathrm{mmHg}$ for systolic pressure and $75.7 \pm 8.3$ for diastolic pressure. A total of $14.5 \%$ (Interval of confidence, $\mathrm{IC}_{95 \%}: 10.5 \sim 19.3$ ) had systolic blood pressures $>140 \mathrm{mmHg}$ and 4.8\% ( $\mathrm{IC}_{95 \%}: 2.6 \sim 8.1$ ) with diastolic blood pressures $>90 \mathrm{mmHg}$. These numbers are considered as the entry points to level 1 of hyper blood pressure. Systolic pressure correlated with BMI $(r=0.22, p<0.001)$ but not with age and physique. Diastolic pressure correlated with age $(r=0.15, \mathrm{p}<0.01)$ and $\mathrm{BMI}(\mathrm{r}=0.28$, $\mathrm{p}<$ 0.001) but not with physique. There was no significant relationship between blood pressure and dietary intakes and no relationship with the level of urbanization. 


\section{Status of children}

Birth weight were measured at the hospitals were mothers gave birth and retrieved from children health records. The mean birth weight was $3.08 \pm 0.45 \mathrm{~kg}$ (median: $3.1 \mathrm{~kg} ; 25^{\text {th }}$ percentile: $2.8 \mathrm{~kg}$ and $75^{\text {th }}$ percentile: $3.4 \mathrm{~kg}$ ). At birth, girls were heavier than boys after adjusting for the year of visit effect (girls $3.15 \pm 0.49 \mathrm{~kg}$ versus boys $2.9 \pm 0.45 \mathrm{~kg}, \mathrm{~F}=7.5, \mathrm{p}<$ 0.006). There was no relationship with the level of urbanization. About $10 \%$ of babies were of low birth weight (LBW) with weights lower than $2.5 \mathrm{~kg}(10.4 \%$; IC 95\% $7.0 \sim 14.7 \%)$. There were no differences in prevalence of LBW in relation to sex or urbanization strata.

The prevalence of malnourished children remained steady during the study with wasting (Weight for height <-2 z-scores) being 7.3\% (IC 95\%: 4.5 11.0\%) and stunting (Height for age <-2 z-scores) 14.2\% (IC 95\%: $10.2 \sim 18.8 \%$ ). The prevalence of thinness (Weight for age <2 z-scores) was $15.2 \%$ (IC 95\%: $11.1 \sim 20.1 \%$ ). There were no sex differences. The prevalence of stunting was not related to the level of urbanization.

Table V presents a comparison of the mean values of child nutrition indices during the two visits, taking into account the year of visit and the sex effect, performed with a general model of variance analysis. The difference in child numbers is due to the inclusion of new born babies in the cohort in the second year of surveys. The W-H index remained steady from one visit to another while there was deterioration in the H-age index. It is noteworthy that there was also a significant difference according to sex (without any interaction between visits and sex) meaning that the progression of growth stunting was more severe for boys. W-age values tented to decrease with time but the differences were not significant. Boys had lower nutritional indices than girls. There was no urbanization effect on child nutritional indices.

Figure 1 illustrates the progressive worsening of growth retardation with age $(\mathrm{F}=3.4 ; \mathrm{p}<0.01)$ and the difference according to sex $(\mathrm{F}=4.3 ; \mathrm{p}<0.04)$ after adjusting for the year of visit effect. Physique was close to the median of the reference during the first six months of life, but thereafter there was a dramatic fall that ceased at around nine months in girls and leveled off thereafter. In boys, the deterioration was a continuing process.

\section{Relationships between mothers and children}


To further elucidate the relationships between child growth (H-age), age of mother, birth weight, maternal status and urbanization level a multiple regression analysis was run. The level of urbanization was added as categorical variable. Visit number was also entered to take into account the repetition of measurements. There was no multi-collinearity between variables. Residuals were normally distributed without significant serial correlations. Table VI displays the results. The model was pertinent $(\mathrm{F}=12.4, \mathrm{p}<0.0001)$ and explained $20 \%$ of the variability of $\mathrm{H}$-age $\left(\mathrm{R}^{2}=0.20\right)$. The most powerful determinant of $\mathrm{H}$-age variability was the birth weight. H-age was also significantly and positively associated with the mother's stature and the sex (girls) of the child. Interestingly, living in strata 2, was negatively related to H-age. 


\section{Discussion}

Two major findings emerge from this study: 1) dietary intakes were generally low and eating habits may vary according to the place of residence; 2 ) there existed a progressive stunting in growth of children related to maternal characteristics and sex.

Dietary intakes reported here were lower than those currently recommended for energy and some important nutrients (folic acid, calcium, iron). The main staple food was sticky rice (Oryza sativa var. glutinosa) which has a lower amylase content than normal white rice (Roder et al. 1996). Weaknesses in the 24 hour recall, and in particular the memory bias that tends to over or underestimate the amounts of foods eaten are acknowledged. However, it has been shown that while variability of estimates is greater than the direct weighing method, the median values are similar (Todd et al. 1983) . Besides, if the dietary recall can be repeated the accuracy of estimates is improved. This was the case here, where the questionnaire was twice answered with similar results. Without being able to ascertain the accuracy of the results, we nonetheless believe that the reported deficiency in energy and in some nutrient intakes is assuredly correct.

We have been unable to compare our results with other food consumption surveys in Vientiane or in other Lao cities since no such surveys have been published. An unpublished working paper written two decades ago reports estimates of energy intakes to be between 1,745 and 1,976 kcal per capita in Vientiane capital (reported in (Kachondham and Dhanamitta 1992) . This figure is higher than ours. Protein intakes were lower: about $45 \mathrm{~g}$ against $92 \mathrm{~g}$ in the present study. Contributions of food groups were also different: cereals (mainly rice) provided $80 \%$ of the energy and $50 \%$ of the protein intake whereas in our study, rice made a smaller contribution to both energy (41\%) and protein (15\%) intake. This suggests that a noticeable change in eating habits may have occurred since then, especially in terms of a greater consumption of foods of animal origin.

Our data point to differences in food patterns related to urbanization levels: in the central belt (strata 1) women consumed more meat and milk but less cereals and fish than those in the outskirts (strata 2 and 3). This could be interpreted as evidence of a transitional process in central urbanized areas while peripheral zones retain many characteristics of a traditional Lao diet (rice and fish from the Mekong River or ponds). This finding could be further refined by information given by FDS scores. They are higher in the central (strata 1) and in the second 
urbanized belt (strata 3) than in first urbanized belt (strata 2). Interestingly our median FDS score was very close to that found in a national Lao survey conducted in 2005: 49.5 versus 51.1 (Kennedy, Berardo et al. 2010). The first urbanized belt (strata 2) appears to offer a less diverse diet than does either the central zone (strata 1) or the more agricultural zone (strata 3 ). For this reason it could be hypothesized that it is more vulnerable than either strata 1 or

3. Urban space is not clearly delineated in Vientiane and there exists a continuity with rural landscapes (Vallée 2008). Urban agriculture is still a major and dynamic economic activity in Vientiane capital. It is not restricted to market gardening but also includes rice growing and fish farming. Such changes at a micro scale have been observed in rural Katu villages from southern Lao PDR and which resulted in a forced movement away from their traditional land (Krahn 2005). In the present study items like fruits, vegetables, legumes and fish contribute $23.8 \pm 12.4 \%$ of energy and $32.9 \pm 19.7 \%$ of protein requirements. These food items are thought to be healthier than meat, animal fat or sweetened drinks (Delisle et al. 2009). Though a process of transition is certainly operating in Lao cities, it seems to be taking place slowlyat a slower rate, with subtle variations according to the place of residence and social background, than . This is in contrast to that reportedin the two neighboring countries of Vietnam (Khan and Khoi 2008) and Thailand (Kosulwat 2002). Indeed, some findings ( $14.5 \%$ of women with high systolic blood pressure and $20.5 \%$ presenting as overweight) indicate that women from Vientiane are at risk of degenerative diseases associated with the nutritional transition phenomenon. These figures are close to those observed in the sister country of Cambodia (King et al. 2005).

This study points to a progressive deficit in height growth, more pronounced in boys than in girls in Lao PDR. In addition, regression analysis suggests that growing patterns varied according to the level of urbanization of the child's place of residence. The percentage of stunted children in our sample $(14.2 \%)$ was about twice lower less than half than that reported at the national level for urban children (32.3\%) or for children aged 1 to 2 years (48.7\%) (Data from the 2006 National Survey; WHO Global Database on Child Growth and Malnutrition, July 2009). However wasting prevalence $7.3 \%$ in the present study was almost the same as that at the national level for urban children (6.9\%). This indicates that the causes of wasting and stunting are different. It has been suggested that both conditions are the end result of different nutritional deficiencies (Golden 1991). The prevalence of wasting has decreased uniformly throughout the country, probably as a direct consequence of global 
improvement in the health sector (better access to medical care and prevention of infectious diseases, better surveillance of pregnant and lactating women, better management of severe malnutrition) than observed elsewhere (Paul et al. 2011). Stunting has decreased markedly in Lao cities but is still excessively high in rural areas (50 to 52\%, according to the Lao National Survey 2006, WHO Global Database). In a recent survey in the same areas of Vientiane, using a representative sample of 0-5 year old children, a prevalence of 23\% (20.3 25.2) was found. This was lower than that in the national survey but higher than our figure (Vallée 2008). Wasting prevalence was very similar to ours (7.7\%). Discrepancies in the prevalence of stunting could be due to the age structure of the sample, suggesting a long lasting effect of stunting without catch up growth. In addition, a significant effect of the level of urbanization on the prevalence of stunting was observed (Vallée 2008). This Stunting was greater in strata $2(21.1 \%)$ and $3(27.5 \%)$ than in strata $1(16.8 \%)$. While the smallness of our sample does not allow a firm conclusion, our findings are in line with this finding.

The apparent sex differences in growth deterioration have also been observed elsewhere. In a recent prospective cohort study performed in Thailand, it was shown that the incidence of stunting was significantly greater in boys than in girls (Mongkolchati et al. 2010) . Likewise, in Africa, examination of results of 16 Demographic and Health Surveys (DHS) across ten different countries, indicated that the prevalence of stunting was greater among boys than girls and that girls had greater mean z-scores than boys (Wamani et al. 2007). Aside from biological explanations, the authors proposed that boys were less robust and more vulnerable to health inequalities than were girls, especially those in the poorer socio-economic strata. However, other studies have demonstrated the reverse. In India, a greater nutritional morbidity was observed in girls (Bharati et al. 2009). In a large survey covering 26 states and more than 25,000 children, it was reported that girls were more frequently underweight and stunted than were boys. The authors stated that this was almost certainly due to discrimination in terms of access to health care to the detriment of girls and not to any discrimination in the allocation of food. Thus, a cultural influence should not be overlooked. This could be the case here where women and girls have a highly valued position in Lao society.

It is acknowledged that stunting is a progressive process, beginning in-utero and preventing the children from achieving their full genetic potential for growth (Dewey and Begum 2011). Several studies have already stressed an association between stunting during infancy and lower fine motor abilities (Chang 2010), motor performances and physical working capacity 
(Benefice et al. 1999), poor psychological and emotional functioning (Walker et al. 2007), and low school achievement (Martorell and Nguyen 2010), 2010). A recent study conducted in Vientiane in children between 36 and 44 months, using the Denver Development Screening Test, demonstrated that there existed a significant association between growth retardation and language acquisition and social/personal skills (Akkavong 2009). Slow child development could lead to suboptimal physical functioning during adulthood and eventually to low economic productivity (Florencio et al. 2008), closing the vicious circle linking malnutrition, poverty and the development of human capital (Dufour et al. 1997; Carba et al. 2009) (Dufour, Staten et al. 1997; Carba, Tan et al. 2009). In addition, our results indicated that height growth of children was significantly related to their mother's stature, proving the existence of an inter-generational effect. This confirm our fears about this issue (Ozaltin, Hill et al. 2011).

For this reason, and though real progress has been realized in recent years, policies aiming at reducing growth retardation without a swing over to over nutrition and obesity should be implemented. These must emphasize the positive outcomes of the ongoing transition while tackling improved access to health care and education especially for poor women living in the less developed urban belts. 


\section{List of tables}

Table I Daily intake of macronutrients by Lao women

Table II Fulfillment (percentages) of nutritional requirements by Lao women

Table III Contribution of food group to energy content of the diet according to 3 urbanization levels

Table IV Physical characteristics of women $(\mathbf{n}=\mathbf{1 5 2})$

Table V Evolution of Trend in nutritional indices of children during the survey

Table VI Multiple regression analysis between $\mathrm{H}$-age, child and mother characteristics and urban strata

\section{List of figures}

Figure 1: Height-age values at different ages 


\section{References}

Akkavong, A. (2009). Retard de croissance et développement psycho moteur des enfants de 36-44 mois en zone péri-urbaine de Vientiane. 4ème suivi de cohorte, année 2008 Mastère en médecine tropicale et santé internationale, Université des Sciences de la Santé, RDP Lao.

Anonym (2006). Lao PDR Multiple Indicators Survey. Final report. Vientiane. Lao PDR, Department of Statistics and UNICEF.

Benefice, E., T. Fouere and R. M. Malina (1999). Early nutritional history and motor performance of Senegalese children, 4-6 years of age. Ann Hum Biol 26(5): 443-455.

Bharati, P., S. Bharati, M. Pal, S. Chakrabarty, S. Som and R. Gupta (2009). Growth and nutritional status of pre-school children in India: rural-urban and gender differences. Coll Antropol 33(1): 7-21.

Carba, D. B., V. L. Tan and L. S. Adair (2009). Early childhood length-for-age is associated with the work status of Filipino young adults. Econ Hum Biol 7(1): 7-17.

de Onis, M., M. Blossner and E. Borghi (2012). Prevalence and trends of stunting among preschool children, 1990-2020. Public Health Nutr 15(1): 142-148.

de Onis, M., E. A. Frongillo and M. Blossner (2000). Is malnutrition declining? An analysis of changes in levels of child malnutrition since 1980. Bull World Health Organ 78(10): 1222-1233.

Delisle, H. F., J. Vioque and A. Gil (2009). Dietary patterns and quality in West-African immigrants in Madrid. Nutr J 8: 3.

Dewey, K. G. and K. Begum (2011). Long-term consequences of stunting in early life. Matern Child Nutr 7 Suppl 3: 5-18.

Dufour, D. L., L. K. Staten, J. C. Reina and G. B. Spurr (1997). Living on the edge: dietary strategies of economically impoverished women in Cali, Colombia. Am J Phys Anthropol 102(1): 5-15.

Ferreira, H. S., F. A. Moura, C. R. Cabral, Jr., T. M. Florencio, R. C. Vieira and M. L. de Assuncao (2009). Short stature of mothers from an area endemic for undernutrition is associated with obesity, hypertension and stunted children: a population-based study in the semi-arid region of Alagoas, Northeast Brazil. Br J Nutr 101(8): 1239-1245.

Florencio, T. T., H. S. Ferreira, J. C. Cavalcante, M. L. Assuncao and A. L. Sawaya (2008). Short stature and food habits as determining factors for the low productivity of sugarcane labourers in the State of Alagoas, north-eastern Brazil. Arch Latinoam Nutr 58(1): 33-39.

Golden, M. H. (1991). The nature of nutritional deficiency in relation to growth failure and poverty. Acta Paediatr Scand Suppl 374: 95-110.

Gurney, J. M. and D. B. Jelliffe (1973). Arm anthropometry in nutritional assessment: nomogram for rapid calculation of muscle circumference and cross-sectional muscle and fat areas. Am J Clin Nutr 26(9): 912-915.

Hamill, P. (1977). NCHS growth curves for children. Vital and health statistics: Series 11. D. o. H. a. Welfare. Washington, National Center for Health Statistics.: 81.

Johnson, C. L., R. Fulwood, S. Abraham and J. D. Bryner (1981). Basic data on anthropometry and angular measurements of the hip and knee joints, for selected groups 1-74 years of age, United States, 1971-1975. Data from the National Health Survey. Vital and health statistics : Series 11. D. P. N. P. 81-1669. Hyattsville, US Dept. of Health and Human Services.: 76. 
Kachondham, Y. and S. Dhanamitta (1992). A new horizon: Addressing food and nutrition problems in the Lao people's Democratic Republic. Food and Nutrition Bulletin 14: 79-87.

Kennedy, G., A. Berardo, C. Papavero, P. Horjus, T. Ballard, M. Dop, J. Delbaere and I. D. Brouwer (2010). Proxy measures of household food consumption for food security assessment and surveillance: comparison of the household dietary diversity and food consumption scores. Public Health Nutr 13(12): 2010-2018.

Khan, N. C. and H. H. Khoi (2008). Double burden of malnutrition: the Vietnamese perspective. Asia Pac J Clin Nutr 17 Suppl 1: 116-118.

King, H., L. Keuky, S. Seng, T. Khun, G. Roglic and M. Pinget (2005). Diabetes and associated disorders in Cambodia: two epidemiological surveys. Lancet 366(9497): 1633-1639.

Kosulwat, V. (2002). The nutrition and health transition in Thailand. Public Health Nutr 5(1A): 183-189.

Krahn, J. (2005). The dynamics of dietary change of transitional food systems in tropical forest areas of Southeast Asia. The contemporary and traditional food system of the Katu in the Sekong Province, Lao PDR Doktor der Ernährungs- und Haushaltswissenschaft, Rheinischen Friedrich-Wilhelms- Universität.

Lévi, P. (2009). Suivi démographique et de scolarisation à Vientiane : 1. Rapport d'enquête : 2. Rapport annexe de présentation des questionnaires 2006-2008. Présentation des principaux résultats d'un suivi de population en milieu urbain, dans une capitale asiatique, Vientiane, ville de taille moyenne au Laos (2009). L. P.-E.-D. (LPED). Marseille, IRD (UMR 151): 94.

Lohman, T. G., A. Roche and R. Martorell (1988). Anthropometric standardization reference manual. Abridged version. Champaign, Illinois, Human kinetics Books.

Martorell, R. and P. Nguyen (2010). Interrelationship between growth and development in low and middle income countries. Nestle Nutr Workshop Ser Pediatr Program 65: 99118; discussion 118-121.

Misra, A. and L. Khurana (2009). The metabolic syndrome in South Asians: epidemiology, determinants, and prevention. Metab Syndr Relat Disord 7(6): 497-514.

Misra, A., N. Singhal, B. Sivakumar, N. Bhagat, A. Jaiswal and L. Khurana (2011). Nutrition transition in India: Secular trends in dietary intake and their relationship to diet-related non-communicable diseases. J Diabetes 3(4): 278-292.

Mongkolchati, A., B. Thinkhamrop, L. Mo-Suwan, U. Chittchang and C. Choprapawon (2010). Prevalence and incidence of child stunting from birth to two years of life in Thai children: based on the Prospective Cohort Study of Thai Children (PCTC). J Med Assoc Thai 93(12): 1368-1378.

Ozaltin, E., K. Hill and S. V. Subramanian (2011). Association of maternal stature with offspring mortality, underweight, and stunting in low- to middle-income countries. Jama 303(15): 1507-1516.

Paul, V. K., H. S. Sachdev, D. Mavalankar, P. Ramachandran, M. J. Sankar, N. Bhandari, V. Sreenivas, T. Sundararaman, D. Govil, D. Osrin and B. Kirkwood (2011).

Reproductive health, and child health and nutrition in India: meeting the challenge. Lancet 377(9762): 332-349.

Popkin, B. M. and P. Gordon-Larsen (2004). The nutrition transition: worldwide obesity dynamics and their determinants. Int J Obes Relat Metab Disord 28 Suppl 3: S2-9.

Roder, W., B. Keoboulapha, K. Vannalath and B. Phouaravanh (1996). Glutinous rice and its importance for hill farmers in Laos. Economic Botany 50(4): 401-408. 
Todd, K. S., M. Hudes and D. H. Calloway (1983). Food intake measurement: problems and approaches. Am J Clin Nutr 37(1): 139-146.

Vallée, J. (2008). Urbanisation et santé à Vientiane (Laos): Les disparités spatiales de santé dans la ville Thèse présentée pour obtenir le grade de Docteur en Géographie Humaine de l'Université de Paris X Nanterre, Paris X Nanterre.

Walker, S. P., S. M. Chang, C. A. Powell, E. Simonoff and S. M. Grantham-McGregor (2007). Early childhood stunting is associated with poor psychological functioning in late adolescence and effects are reduced by psychosocial stimulation. J Nutr 137(11): 2464-2469.

Wamani, H., A. N. Astrom, S. Peterson, J. K. Tumwine and T. Tylleskar (2007). Boys are more stunted than girls in sub-Saharan Africa: a meta-analysis of 16 demographic and health surveys. BMC Pediatr 7: 17.

Waterlow, J. (1972). Classification and definition of protein-calorie malnutrition. British Medical Journal 3 (5826)(Sep 2): 566-569.

WFP (2011). Lao PDR Country Strategy 2011-2015. Vientiane, World Food Program: 20.

WHO (1995). Physical status: The use and interpretation of anthropometry. Report of a WHO expert committee. Geneva, World Health Organization.

Zhai, F., H. Wang, S. Du, Y. He, Z. Wang, K. Ge and B. M. Popkin (2009). Prospective study on nutrition transition in China. Nutr Rev 67 Suppl 1: S56-61. 
Figure 1: Height-age values at different ages

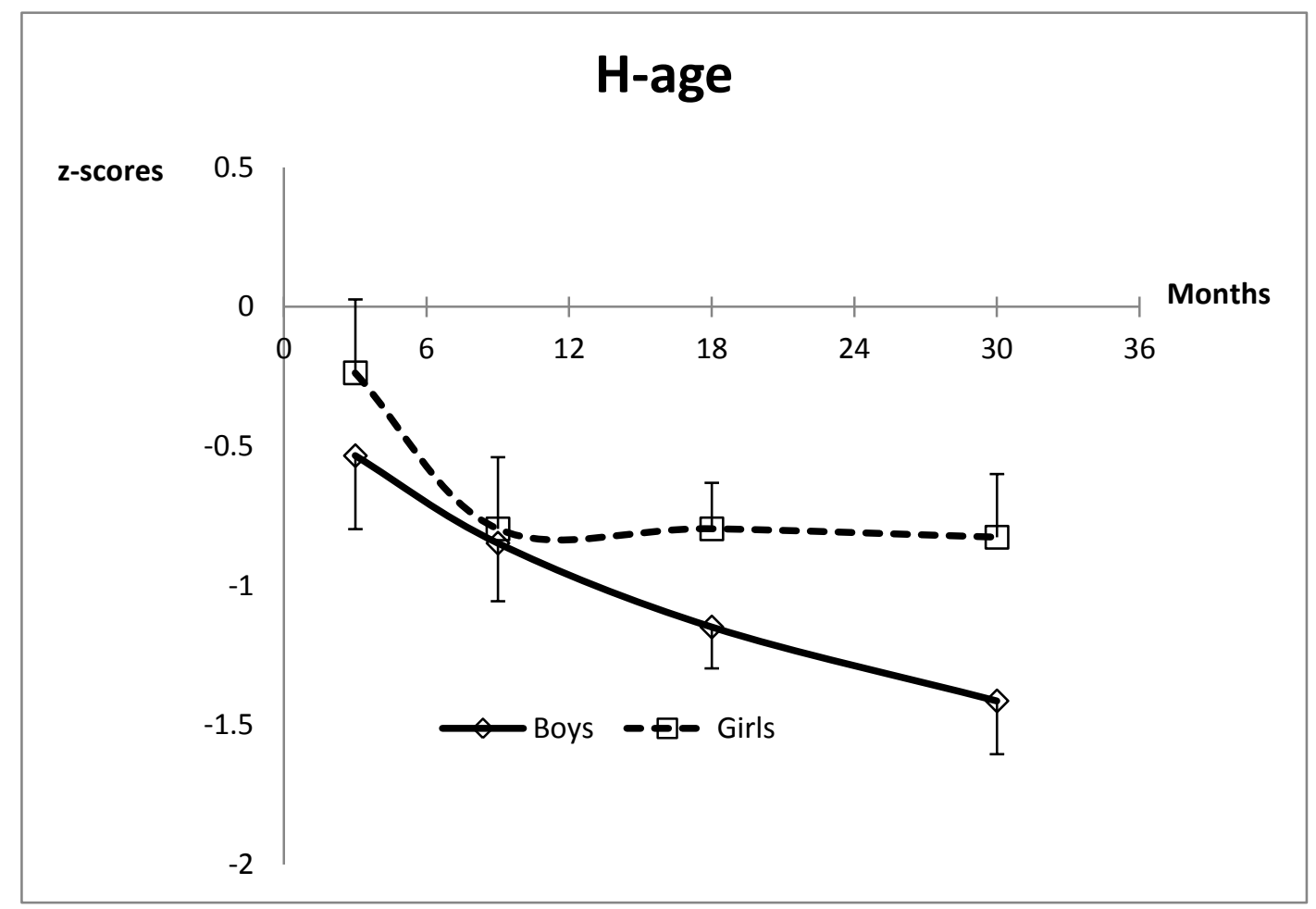


Table I Daily intake of macronutrients by Lao women

\begin{tabular}{lcccc}
\hline & $\begin{array}{c}\text { Energy } \\
\mathrm{kcal}\end{array}$ & Protein & Fat & $\mathrm{CHO}$ \\
& $\mathrm{g}$ & $\mathrm{g}$ & $\mathrm{g}$ \\
\hline Crude value & $1,620.7^{1}$ & 92.6 & 47.8 & 205.1 \\
& $344.9^{2}$ & 30.2 & 19.0 & 54.7 \\
& & & & \\
$\begin{array}{l}\text { Energy } \\
\text { percentage }\end{array}$ & - & 23.0 & 25.8 & 51.2 \\
& - & 5.0 & 8.2 & 8.7 \\
\hline
\end{tabular}

${ }^{1}$ mean, ${ }^{2}$ standard deviation) 
Table II Fulfillment (percentages) of nutritional requirements by Lao women

\begin{tabular}{lccc}
\hline & 25 th & 50 th & 75 th \\
& Percentile & Percentile & Percentile \\
\hline Energy & 70.9 & 85.3 & 94.6 \\
Polyunsaturated fatty acids & 45.8 & 81.3 & 118.9 \\
Vit A & 31.7 & 53.6 & 91.0 \\
Vit B1 & 117.8 & 164.5 & 230.3 \\
Vit B2 & 80.6 & 107.5 & 138.5 \\
Vit B6 & 85.2 & 121.7 & 150.2 \\
Total folic acid & 31.4 & 49.8 & 68.4 \\
Vit C & 96.2 & 155.3 & 242.6 \\
Calcium & 22.5 & 32.8 & 47.7 \\
Iron & 58.0 & 76.1 & 96.4 \\
Zinc & 108.3 & 144.1 & 189.9 \\
\hline
\end{tabular}


Table III Contribution of food group to energy content of the diet according to 3 urbanization levels

\begin{tabular}{|c|c|c|c|c|c|c|}
\hline Item & Strata & Mean & $\mathrm{SE}$ & $\mathrm{F}$ & $p^{1}$ & Conclusions \\
\hline \multirow[t]{3}{*}{ Cereals } & 1 & 38.4 & 1.5 & 2.7 & 0.06 & $1<2,3$ \\
\hline & 2 & 41.3 & 1.2 & & & \\
\hline & 3 & 42.4 & 1.2 & & & \\
\hline \multirow[t]{3}{*}{ Meat } & 1 & 24.9 & 1.2 & 3.7 & 0.02 & $1>2,3$ \\
\hline & 2 & 22.2 & 1.0 & & & \\
\hline & 3 & 20.5 & 1.0 & & & \\
\hline \multirow[t]{3}{*}{ Fish } & 1 & 5.6 & 0.9 & 3.4 & 0.03 & $1<2,3$ \\
\hline & 2 & 7.2 & 0.7 & & & \\
\hline & 3 & 8.8 & 0.8 & & & \\
\hline \multirow[t]{3}{*}{ Fruit } & 1 & 7.8 & 0.7 & 2 & ns & \\
\hline & 2 & 6.7 & 0.5 & & & \\
\hline & 3 & 6.0 & 0.6 & & & \\
\hline \multirow[t]{3}{*}{ Fat } & 1 & 7.1 & 0.7 & 0.2 & ns & \\
\hline & 2 & 6.5 & 0.6 & & & \\
\hline & 3 & 6.6 & 0.6 & & & \\
\hline \multirow[t]{3}{*}{ Vegetables } & 1 & 5.4 & 0.5 & 0.8 & ns & \\
\hline & 2 & 5.4 & 0.4 & & & \\
\hline & 3 & 6.2 & 0.4 & & & \\
\hline \multirow[t]{3}{*}{ Legumes } & 1 & 3.2 & 0.8 & 0.9 & $\mathrm{~ns}$ & \\
\hline & 2 & 4.5 & 0.6 & & & \\
\hline & 3 & 3.7 & 0.6 & & & \\
\hline \multirow[t]{3}{*}{ Eggs } & 1 & 2.3 & 0.4 & 1.1 & ns & \\
\hline & 2 & 2.1 & 0.3 & & & \\
\hline & 3 & 1.6 & 0.3 & & & \\
\hline \multirow[t]{3}{*}{ Milk } & 1 & 1.6 & 0.3 & 4.5 & 0.01 & $1>2,3$ \\
\hline & 2 & 0.9 & 0.2 & & & \\
\hline & 3 & 0.4 & 0.2 & & & \\
\hline \multirow[t]{3}{*}{ Sweet } & 1 & 2.3 & 0.3 & 1.8 & ns & \\
\hline & 2 & 1.9 & 0.2 & & & \\
\hline & 3 & 2.5 & 0.3 & & & \\
\hline
\end{tabular}

${ }^{1} \mathrm{p}$ value; ns: not significant 
Table IV Physical characteristics of women $(\mathbf{n = 1 5 2})$

\begin{tabular}{lccccc}
\hline & Mean & SD & Percentile 25 & Median & Percentile 75 \\
\hline Weight $(\mathrm{kg})$ & 52.2 & 8.7 & 46.6 & 51.4 & 56.9 \\
Height $(\mathrm{cm})$ & 152.8 & 4.8 & 149.7 & 152.3 & 155.7 \\
Sitting height $(\mathrm{cm})$ & 81.4 & 2.8 & 79.4 & 81.5 & 83.3 \\
Arm circ $(\mathrm{cm})$ & 25.2 & 3.0 & 23.2 & 24.9 & 26.9 \\
MAC $(\mathrm{cm})$ & 19.8 & 1.9 & 18.5 & 19.9 & 20.9 \\
Triceps skf (mm) & 14.0 & 5.2 & 10.05 & 13.1 & 17.05 \\
Biceps skf $(\mathrm{mm})$ & 6.2 & 3.0 & 3.95 & 5.6 & 7.7 \\
BMI $\left(\mathrm{kg} / \mathrm{m}^{2}\right)$ & 22.3 & 3.4 & 20.1 & 21.6 & 24.4 \\
\hline
\end{tabular}


Table V Evolution Trends in of nutritional indices values of children during the survey

\begin{tabular}{|c|c|c|c|c|c|c|}
\hline Visit & W-H boys & W-H girls & $\begin{array}{c}\text { H-age } \\
\text { boys }\end{array}$ & $\begin{array}{c}\text { H-age } \\
\text { girls }\end{array}$ & $\begin{array}{c}\mathrm{W} \text {-age } \\
\text { boys }\end{array}$ & $\begin{array}{c}\text { W-age } \\
\text { girls }\end{array}$ \\
\hline 2008 & -0.64 & -0.41 & -0.83 & -0.58 & -0.94 & -0.63 \\
\hline$(n=122)$ & 0.14 & 0.15 & 0.14 & 0.16 & 0.13 & 0.15 \\
\hline 2009 & -0.56 & -0.50 & -1.26 & -0.82 & -1.03 & -0.76 \\
\hline$(n=156)$ & 0.12 & 0.14 & 0.13 & 0.15 & 0.12 & 0.14 \\
\hline \multirow[t]{2}{*}{ Visit effect } & \multicolumn{2}{|l|}{$0.0^{1}$} & \multicolumn{2}{|l|}{5.3} & \multicolumn{2}{|l|}{0.6} \\
\hline & \multicolumn{2}{|l|}{$\mathrm{ns}^{2}$} & \multicolumn{2}{|l|}{0.02} & \multicolumn{2}{|l|}{ ns } \\
\hline \multirow[t]{2}{*}{ Sex effect } & \multicolumn{2}{|l|}{1.2} & \multicolumn{2}{|l|}{5.7} & \multicolumn{2}{|l|}{4.7} \\
\hline & \multicolumn{2}{|l|}{ ns } & \multicolumn{2}{|l|}{0.01} & \multicolumn{2}{|l|}{0.03} \\
\hline
\end{tabular}

\footnotetext{
${ }^{1} \mathrm{~F}$ value

${ }^{2}$ p value; ns: not significant
} 
Table VI Multiple regression analysis between $\mathrm{H}$-age, child and mother characteristics and urban strata

\begin{tabular}{lccccc}
\hline $\begin{array}{l}\text { Independent } \\
\text { Variable }\end{array}$ & $\begin{array}{l}\text { Regression } \\
\text { Coefficient }\end{array}$ & Standard error & t-value & $\mathrm{p}$ & Partial R $^{2}$ \\
\hline & & & & & \\
Birth weight & 0.886 & 0.157 & 5.640 & 0.000 & 0.116 \\
$\begin{array}{l}\text { Sex (girls) } \\
\text { Urban }\end{array}$ & 0.467 & 0.146 & 3.208 & 0.002 & 0.041 \\
strata=2 & -0.435 & 0.179 & -2.429 & 0.016 & 0.024 \\
$\begin{array}{l}\text { (Urban } \\
\text { strata=3) }\end{array}$ & -0.280 & 0.185 & -1.514 & $\mathrm{~ns}$ & - \\
$\begin{array}{l}\text { Mother } \\
\text { stature }\end{array}$ & 0.051 & 0.014 & 3.541 & 0.001 & 0.049 \\
Mother age & -0.025 & 0.015 & -1.672 & $\mathrm{~ns}$ & - \\
Mother BMI & 0.011 & 0.021 & 0.539 & $\mathrm{~ns}$ & - \\
\hline
\end{tabular}

